УДК 159.922 .7

DOI https://doi.org/10.32838/2709-3093/2020.4/21

\title{
Полішук С.A.
}

Інститут соціальної та політичної психології

Національної академії педагогічних наук України

\section{ЕМОЦЙНА І ВОЛЬОВА САМОРЕГУЛЯЦІЯ ЛІТНІХ ЛЮДЕЙ У НАДЗВИЧАЙНИХ СИТУАЦІЯХ}

\begin{abstract}
Актуалізується проблематика конструктивної поведінки людини під час загрозливих природних і соціальних викликів, зокрема у надзвичайних ситуаиіях. Як приклад розглядаються психологічні особливості конструктивної поведінки людей літнього віку як реальних $i$ потенційних суб 'єктів стабільного суспільного розвитку (об'єктивні гаранти внутрішньої $і$ зовнішньої держсавної стабільності через використання значущого індивідуального досвіду). На основі авторського пілотажного дослідження розроблено теоретичний $і$ практичний аспекти иієї проблеми (конструктивна поведінка - це набута форма індивідуального психологічного захисту). Ї̈ розв'язання передбачає формування доказової інформачійної бази про високу «спроможність до збереження якості життя» у літньому віщі на рівні попередніх вікових періодів $i$, як наслідок, заперечення поширених негативних стереотипів про його можливості (фізичні, інтелектуальні, вольові тощо). Визначено первинну (емоційна регуляція) та вторинну умови (вольова регуляція) конструктивної поведінки. Встановлено пізнавальні пріоритети системи адаптації до нової жстттедіяльності (у иьому контексті проаналізовані окремі концептуальні наукові уявлення відомих дослідників). Показано, що емоційна та вольова саморегуляція мають виразні структуровані смислові прояви. Їх базовий зміст започатковується у дитинстві на перших вікових етапах життєвого шляху людини. Розроблено проєкт особистісної типології емоційної саморегуляиії літніх людей, яка дозволяє диферениіювати та вдосконалювати прояви конструктивної поведінки. Наголошується на необхідності розроблення доказового діагностичного інструментарію для дослідження сформованості емоційної і вольової саморегуляиії людей літнього віку для констатування, формування та прогнозування їхньої конструктивної поведінки у надзвичайних ситуачіях з перспективою збереження $і$ змічнення фізичного та психічного здоров'я.
\end{abstract}

Ключові слова: вольова саморегулячія, емоиійна саморегулячія, конструктивна поведінка, літній вік, надзвичайна ситуачія, психологічний захист.

Постановка проблеми. Мета статті передбачає актуалізацію у громадянському суспільстві «необхідності світоглядної позиції про «літній вік» як рівноправний етап життєвого шляху людини» через подолання наявних негативних суспільних стереотипів про «старість», спроможність до збереження якості життя, зокрема у надзвичайних ситуаціях:

1) теоретико-методологічний аспект: формування образу «літньої людини» як вершини індивідуального життєвого досвіду, завдяки якому вона постає об'єктивним гарантом соціально-психологічного взаєморозуміння між поколіннями та збереження державної ідентичності, публічне оприлюднення значущості феномена «продуктивність та якість життя людини» на всіх етапах життєвого шляху (прогнозований результат: партнерське ставлення до літніх людей та їхня психологічна безпека як самобутніх суб'єктів держави, цінних для iї глобальної стабілізації та розвитку; подолання геронтофобії, прояви якої загострюються зокрема в умовах пандемії);

2) практичний аспект (на основі емпіричного вивчення сутності проблеми): 3'ясування умов психологічної безпеки громадян літнього віку через встановлення у них типових, або об'єднуючих (професія, сім'я, життєві цінності тощо), та нетипових, або індивідуальних особливостей (емоційно-вольова саморегуляція, тау-тип тощо) (прогнозований результат: розроблення шляхів формування необхідних знань, умінь i навичок їхнього психологічного захисту у надзвичайних ситуаціях.

Аналіз останніх досліджень i публікацій. Зазначена проблематика 3 1990-х рp. перебуває у центрі дослідницької уваги зокрема: М. Єрмолаєвої, І. Малкіної-Пих, Т. Немчин, В. Поліщука, В. Рибалки, Т. Титаренко, Б. Цуканова, В. Чернобровкіна, В. Чернобровкіної, Л. Юр'євої. У зв'язку 3 цим основною сюжетною лінією нашої статті у 
руслі зазначеної постановки проблеми та названих тематичних публікацій є 3'ясування змісту конструктивної поведінки літніх людей як основної набутої форми їхнього психологічного захисту перед різноплановими соціальними викликами, зокрема надзвичайними ситуаціями (на основі пілотного дослідження).

Постановка завдання. Мета статті - встановлення психологічних особливостей емоційної регуляції як первинної умови конструктивної поведінки та вольової регуляції як вторинної умови конструктивної поведінки.

Виклад основного матеріалу. Досвід надання психологічної допомоги людям, які перебувають у критичних та надзвичайних ситуаціях, демонструє функціональну значущість емоційної регуляції та саморегуляції для формування конструктивної поведінки. Як наслідок, «вмикається» система адаптації до нових життєвих умов 3 такими пізнавальними пріоритетами:

1. Перебування у надзвичайній ситуації супроводжується порушеннями внутрішньої психологічної системи діяльності. Виникає необхідність у новій функціональній системі, яка забезпечить психічну адаптації до нових умов.

2. Активність такої функціональної системи визначається взаємодією іiі підсистем, внаслідок чого формуються нові інтегративні якості людини, які сприяють психологічній адаптації.

3. Провідне місце у формуванні названої системи належить саморегуляції, яка виконує дві функції: 1) вплив на несприятливі фактори (природні, соціальні) надзвичайної ситуації; 2) вибір правильної стратегії для ліквідації порушень внутрішньої психологічної системи діяльності.

4. Зняття порушень внутрішньої психологічної системи діяльності можливе через конструктивну поведінку, основною загрозою для якої $\epsilon$ недостатня емоційна саморегуляція, яка спричиняє фрустраційну поведінку 3 такими ознаками: 1) рухове збудження; 2) апатія; 3) агресія і деструкція; 4) стереотипія («сліпий повтор фіксованої поведінки»); 5) регресія (поведінкові моделі минулого/«примітивізм» поведінки (втрата «якості» виконання попередньо набутої конструктивної поведінки) (Р. Баркер, Т. Дембо, К. Левін тощо) [2].

Отже, виникає небезпека «втрати» («відсутності») осмисленої иілі, опредмеченої причиннонаслідковими зв'язками (М. Майєр), що, своєю чергою, не дозволяє поведінці людини бути адаптивною до нових умов життедіяльності. Групи потреб, які початково були джерелом активності, залишаються незадоволеними, тому людина потрапляє у ситуацію фрустрації з великою ймовірністю проявів фрустраційної поведінки.

Водночас завдяки емоційній саморегуляції створюються сприятливі умови для конструктивної поведінки. Це саме та форма активності, яка усвідомлюється і опредмечується причиннонаслідковими зв'язками з бажаною ціллю, забезпечуючи задоволення «вихідних» потреб і створюючи необхідні передумови адаптації до нових умов життєдіяльності.

За Ф. Василюком, варіації поведінкових проявів у критичних ситуаціях залежать від: 1) наявності (відсутності) усвідомленого перспективного зв'язку поведінки з мотивом (як умови конструювання психологічної ситуації через усвідомлення причинно-наслідкових зв'язків поведінки та іiі наслідків); 2) організованості (неорганізованості) поведінки відповідно до мети.

Лише усвідомлений зв'язок поведінки з внутрішніми мотивами, які виникають через опредмечення потреб, сприяє оптимальній (конструктивній) структурованій самоорганізації людини у надзвичайній ситуації:

1) переживання дискомфорту;

2) усвідомлення причини дискомфорту як наслідку порушення певних власних потреб («чого не вистачає»);

3) окреслення осмисленої цілі (побудова стратегіï);

4) покрокове планування поведінки для реалізації осмисленої цілі з урахуванням об'єктивних умов діяльності та суб'єктивних показників своїх можливостей;

5) передбачення наслідків спланованої поведінки;

6) остаточна організація поведінки.

Таким чином, конструктивна поведінка у надзвичайних ситуаціях має бути: 1) «мотиводоцільною» та 2) «організованою метою». Чим більше потреб людини зазнають негативних зрушень, тим вірогідніша полімотивованість поведінки (кілька мотивів можуть впливати на реалізацію однієї потреби; так само одна потреба може реалізовуватися в кількох ієрархічних мотивах). Отже, з'ясування значущості кожного мотиву дозволяє зрозуміти загальні характеристики предметного змісту потреби [7].

Водночас чим нижчі показники емоційної напруги, тим вища операціональна напруга, а значить, більша вірогідність конструктивного відбору ключових мотивів (через первинний етап «розуміння власних потреб») наступних дій, 
передбачення наслідків мотивованої поведінки i, зрештою, «організації поведінки» згідно з осмисленими цілями та усвідомленням цих наслідків. Оскільки емоційна саморегуляція знижує емоційну напругу у ситуаціях загрози життю та здоров'ю людини, то ії вбачають об'єктивною передумовою конструктивної поведінки як єдиного енергозберігаючого i перетворювального механізму побудови «задач розвитку» та життєвих надбань у надзвичайних ситуаціях.

Тепер розглянемо зміст емоційної напруги як результат впливу різних стимулів на рівень активації організму, де показовими $є$ концептуальні положення Д. Хебба:

1) за низької активації організму сенсорні сигнали «не проходять» і не викликають емоцій; водночас дуже висока активація дозволяє надходити надто численній інформації, на яку людина не може відповісти вибірково;

2) зі зростанням рівня активації зростає емотивність, оптимум якої досягається на середньому рівні зміни активації; якщо активація і далі зростає, то збільшуються астенізуючі і дезорганізуючі емоційні прояви. Відповідно, оптимальний рівень емоційних проявів, а значить, відсутність емоційної перенапруги і можливість включення конструктивної поведінки можливі за умови середнього рівня активації організму. Тут необхідно знати вікові особливості цього психічного явища:

1. Із дорослішанням зростає радіус дії емоційного відгуку. У літньому віці він, однак, знову звужується, що пояснює зростаючу реактивність людей, коли їхні реакції на ледь помітні чуттєві подразники стають виразнішими.

2. Дозрівання центральної нервової системи і виховання сприяють зростанню здатності людини до керування емоціями. Це можливе за умови розвиненої довільності поведінки та довільної саморегуляції, яка вперше виявляється у довільних рухах ще на четвертому місяці життя (Ліпсітт) i $\epsilon$ наслідком умовно-рефлекторних кінестетичних сигналів.

О. Леонтьєв «найпростішу модель довільних рухів» у дитячому віці вбачає у переході від функції регулювання за допомогою мовлення дорослого до самостійного мовлення під час виконання мовленнєвої інструкції (схожа позиція у О. Запорожця: довільність регулює рухову поведінку). За Л. Божович, для розвитку довільності поведінки важливо діяти за власними цілями, які відповідають актуальним потребам і усвідомлено приймаються і виконують збуджувальну функцію. Важливу роль тут виконує самоконтроль (вироблені навички внутрішніх спонукань до постійного контролю власних дій і вчинків. - М. Боришевський).

Л. Виготський вважав довільність нижчим рівнем розвитку волі, але довільна дія тоді стає вольовою, коли необхідна мобілізація внутрішніх ресурсів у боротьбі з труднощами, які заважають досягненню поставлених цілей. За Г. Штукою, складниками довільних дій є:

1) цілеспрямованість (високий рівень довільних дій);

2) опосередкованість (здатність використовувати допоміжні засоби з метою виконання діiі);

3) усвідомленість (здатність розуміти мету, мотиви, шляхи їх реалізації та результати сформованих дій) [8]. У схожому контенті довільні дії як нерефлекторні, неінстинктивні, що передбачають намір та планування, усвідомлені причини, контроль і регуляцію, розглядає В. Іванников [5].

Отже, під час оволодіння функціональними властивостями речей у дитини виникає система рухів і дій, формуються образи предметів. Рухові дії стають варіативними, визначаючи стан розвитку і вдосконалення довільної поведінки. Довільність психічних процесів формується завдяки розумному балансу вимог до дитини та надання ій доцільної самостійності. Оскільки дії стають особистісними, а зв'язок між мотивами та цілями ускладнюється, то створюються додаткові умови для розвитку довільності поведінки (В. Котирло). Якщо за довільними діями знаходиться суб'єкт, то за вольовими - особистість (тоді вольову регуляцію слід вважати останньою стадією в оволодінні власною поведінкою і психічними процесами).

В. Іванников наголошує, що функція вольової регуляції має три ступені (довільні процеси на базі потреб; довільні процеси на основі свідомого відображення необхідності і можливості такої регуляції з допомогою мовлення; вольові процеси як особистісний рівень довільної регуляції), а тому вона є особистісним рівнем довільної регуляції спонукання до дії, необхідність якої свідомо прийнята людиною.

3. Під час найбільшої диференціації почуттів зростають фрустраційні переживання і з'являються чуттєві конфлікти. Людина по-різному може реагувати на перешкоди: готовністю до їх переборення або уникненням, нездатністю виконувати нову дію, фантазуванням. Так, у молодшому і старшому віці афективні реакції є дуже увиразненими у стані фрустрації.

4. Індивідуальні відмінності фрустраційних переживань пов'язані з фрустраційною толерант- 
ністю, тобто вмінням тривалий час без особливих зусиль переживати фрустрацію, послаблюючи напруженість різними прямими та опосередкованими засобами (С. Розенцвейг).

За нашими спостереженнями найбільшою фрустраційною толерантністю вирізняються люди 3 розвиненою емоційною саморегуляцією, морфологічним субстратом якої $є$ древні (підкіркові) та пізні за походженням (лобні, вони ж відповідають за довільність поведінки) долі головного мозку.

Система емоційної регуляції контролює енергетичний баланс організму. Взаємодія 3 навколишнім світом, управління потребами людини можуть відбуватися на різних рівнях активності та глибини емоційного контакту із середовищем:

1. Рівень польової реактивності. Пов'язаний 3 найбільш примітивними, пасивними формами психічної адаптації, розв'язує проблеми захисту організму від руйнівних впливів середовища, забезпечує вибір позицій комфорту і безпеки. Афективне переживання від отриманого враження не має явної позитивної чи негативної оцінки. Людина почувається дискомфортно або комфортно у психічному полі. ІЇ̈ відчуття миттєві, нестійкі і викликають неповністю усвідомлену потребу в русі, яку майже неможливо висловити вербально: «Щось змусило обернутися», «Щось не сподобалося». Ця проста і адекватна поведінка дозволяє вибрати для забезпечення психічного комфорту оптимальну просторову позицію (облаштування двору, вулиці, вибір місця відпочинку тощо).

Зміна освітлення, милування сонячним промінням, хмарами, водою, вогнем, шарудінням листя, гармонійними пейзажами заспокоюють людину, створюють у неї відчуття комфорту, а отже, захищеності. Домівка, одяг, пейзаж вносять відчуття гармонії, спокою у внутрішнє емоційне життя.

2. Рівень стереотипів. Регулює процес і шляхи задоволення соматичних потреб, встановлює ефективний контроль за функціями організму, впорядковує психосоматичні відчуття у їх зв'язку 3 актуальними зовнішніми сигналами, інтенсивність яких коригується у відповідності до вітальних потреб.

Тут зростає чутливість до будь-яких порушень потреб, якісно оцінюються сигнали оточення і внутрішнього середовища, де останні більш значущі, яскраві емоційні переживання. Неприйнятні сенсорний дискомфорт, порушення режиму. Виникає синестезія: голос - мелодичний або скрипучий, світло - різке або м'яке, погляд липкий або гострий.
Стійка афективна пам'ять, завдяки якій 3'являється афективний досвід сенсорної взаємодії із середовищем, формуються індивідуальні смаки, звички («не люблю гамору», «люблю рано вставати», «не можу жити без солодкого» тощо), виникають складні форми поведінки.

Важливо зважати на те, що афективна фіксація спричиняє оптимальні манери поведінки і водночас може викликати страх порушення стереотипів.

Рівень стереотипів не годиться для нестабільних життєвих умов. Вибірково посилює стенічні стани, протидіє розвитку астенічних, розвиває способи аутостимуляції радості, задоволення (ссати соску, палець; бігати, гратися іграшками; рифмувати слова; ритмічно постукувати ногою тощо). Іноді людина «прописує» собі прогулянки, біг, відчуття дотику трави, піску.

У культурному розвитку афективні механізми стимулюють соматичну сферу, впливають на складні прийоми підтримки позитивних емоційних станів.

3. Рівень експансії. Починає засвоюватися наприкінці першого року життя, забезпечує активність там, де афективний стереотип поведінки $є$ неефективним. Перешкоди викликають дослідницьку поведінку, формують шляхи переборення труднощів, потребу оцінити власні сили.

Афективні переживання пов'язані 3 досягненням бажаного. Афективна пам'ять накопичує знання про себе, успіхи і поразки, започатковує рівень домагань. Як наслідок, виникає афективне самовідчуття «можу» $\mathrm{i}$ «не можу», що сприяє активній експансії на оточення, коли неочікувані враження не лякають, а цікавлять, перешкоди спричиняють не страх, а гнів, агресію.

Рівень експансії $\epsilon$ енергетично сильним, провідним, дозволяє активно перетворювати окремі неприємні враження у приємні. Він формує афективну потребу у небезпеці, яка може виявитися вербально («жахи», захоплення детективною, пригодницькою літературою).

4. Рівень емочійного контролю. На самовідчуття впливає емоційна оцінка оточення, внаслідок чого розв'язуються складні соціальні проблеми. Афективні переживання, своєю чергою, пов'язані зі співчуттям. Емоційна пам'ять упорядковує процеси сприймання, створює образ надійного, стабільного навколишнього світу, як наслідок, сприяє емоційній упевненості в інших людях, їхніх знаннях. Тоді суб'єкт почувається безпечно, комфортно і не «втікає» від невдач, не виявляє агресії, а звертається за допомогою до оточення [7]. 
Оскільки у кожному випадку посилені базальні рівні впливають на емоційну адаптацію, а значить, емоційну саморегуляцію, то ми попередньо виокремлюємо чотири тематичні типи:

1. «Чутливий» (розвинена здатність до самоспостережень, заглибленість у внутрішні переживання, розуміння власних потреб, прагнення до гармоніі).

2. «Консервативний» (виразна чутливість до зовнішнього світу, розвинена афективна пам'ять, стійкі звички, порушення яких викликає стійкий дискомфорт, причини якого не завжди усвідомлюються).

3. «Сміливий» (готовність до змін, виходу із зони комфорту, розкутість, схильність до ризику).
4. «Контактний» (виразна зосередженість на стосунках, спрямованість на дотримання діючих правил).

Висновки. Визначено теоретико-практичні напрями розроблення валідного діагностичного інструментарію для дослідження сформованості емоційної і вольової саморегуляції людей у надзвичайних ситуаціях.

Встановлено необхідність значущості прогнозування конструктивної поведінки для людей літнього віку у надзвичайних ситуаціях як єдиної «мотиводоцільної» та «організованої», спрямованої зокрема на збереження і зміцнення фізичного та психічного здоров'я.

\section{Список літератури:}

1. Божович Л.И. Личность и ее формирование в детском возрасте. Москва : Просвещение, 1968.464 с.

2. Василюк Ф.Е. Психология переживания (анализ преодоления критических ситуаций). Москва : Изд-во Московского университета, 1984. С. 11-18.

3. Выготский Л.С. К вопросу о динамике детского характера. Москва : Педагогика, 1983. С. $153-165$.

4. Долинська Л.В., Співак Л.М. Геронтопсихологія: Практикум. Хрестоматія : навчальний посібник. Київ : Каравела, 2012. С. 129-228.

5. Иванников В.А. Психологические механизмы волевой регуляции. Москва : Изд-во УРАО, 1998.144 с.

6. Малкина-Пых И.Г. Экстремальные ситуации. Москва : Изд-во Эксмо, 2005. С. 15-17.

7. Поліщук С.А. Методичний довідник з психодіагностики : навчально-методичний посібник. Суми : Університетська книга, 2009. С. 208-215.

8. Штука А.Т. Психологические особенности формирования произвольности действий у младших школьников : дис. ... к. психол. наук : 19.00.07. Киев, 1987. 151 с.

\section{Polishchuk S.A. EMOTIONAL AND VOLITIONAL SELF-REGULATION OF ELDERLY PEOPLE IN EMERGENCIES}

The issue of the constructive human behaviour in the conditions of threatening natural and social challenges, in particular in emergencies, was actualized. As an example, the psychological features of constructive behaviour of elderly people as real and potential subjects of stable social development (objective guarantors of internal and external state stability through the use of meaningful individual experience) were considered. On the basis of the author's pilot research the theoretical and practical aspects of the problem was developed (constructive behaviour as the acquired form of individual psychological protection). Its solution involves forming the evidence base on the high "capacity to maintain quality of life" at old age at the level of the previous age periods, and, as a consequence, the rejection of common negative stereotypes about its capabilities (physical, intellectual, volitional, etc.).

The primary (emotional regulation) and secondary conditions (volitional regulation) of constructive behaviour were determined. The cognitive priorities of the system of adapting to new life activities were established (in this context some conceptual scientific ideas of the well-known researchers were analyzed). It was shown that the emotional and volitional self-regulation have clear structured semantic manifestations. Their basic meaning begins in childhood in the first age stages of human life. The project of the personal typology of the emotional self-regulation of elderly people was developed that allows to differentiate and improve the manifestations of the constructive behaviour. Emphasis was placed on the need to develop evidence-based diagnostic tools to study forming the emotional and volitional self-regulation of elderly people to identify, shape and predict their constructive behaviour in emergencies with the prospect of maintaining and strengthening their physical and mental health.

Key words: volitional self-regulation, emotional self-regulation, constructive behaviour, old age, emergency, psychological protection. 